\title{
Influence of reconciliation programmes on the reconciliation attitudes of war-affected adolescents in Northern Uganda
}

\author{
Benjamin Alipanga (1,2), Maarten De Schryver (5), \\ Stella Neema (4), Eric Broekaert (3), Ilse Derluyn (2)
}

(I) Department of Mental Health and Community Psychology, Makerere University, Uganda

(2) Department of Social Work and Social Pedagogy and Centre for Children in Vulnerable Situations, Ghent University, Belgium

(3) Department of Orthopedagogics, Ghent University, Belgium

(4) Department of Sociology, Makerere University, Uganda

(5) Department of Experimental Clinical and Health Psychology

Ghent University, Belgium

\begin{abstract}
Whether post-conflict reconciliation programmes are able to change hostile behaviours is not known. This study sought to assess the influence of reconciliation programmes on the reconciliation attitudes of war-affected adolescents in two communities in Northern Uganda. Four hundred and forty five adolescents within two communities, one with and the other without interventions were assessed for exposure to war-related and daily stressors and place of residence using hierarchical regression analysis to predict reconciliation attitudes. Adolescents in the non-intervention community recorded more positive and also more negative reconciliation attitudes; exposure to daily and war-related stressors was more positively associated with increasing reconciliation attitudes among adolescents in the non-intervention than those in the intervention community. Overall the programmes recorded limited impact on reconciliation attitudes, perhaps due to the pervasive adverse social situation of the people. Conclusion: there is a need for multi-pronged, collaborative programme efforts targeting holistic recovery programmes with focus on changing negative reconciliation attitudes.
\end{abstract}

Key words: reconciliation attitudes, reconciliation programmes, war-affected adolescents, Northern Uganda

\section{Introduction}

Globally, young people are affected by armed conflicts on a wide scale (DicksonGomez, 2002; Francis, 2007; Pearn, 2003; UN, 1996; Zack-Williams, 200I). In Africa, and particularly in Uganda, children and adolescents were even forced to participate in 
war, as child soldiers in various roles (Betancourt, Borisova, de la Soudière \& Williamson, 20II; Denov, 20I0; McKay, 2004; Ursano \& Shaw, 2007), hereby exposing them to a range of stressors, both during the conflict (so-called "war-related stressors"), and in the postconflict context (“daily stressors") (Honwana, 2008; Pham \& Stover, 2009; Vindevogel, Coppens, De Schryver, Loots, Broekaert, \& Derluyn, 2013). The targeting of civilians in war strategies (for example as child soldiers, but also, amongst others, the use of sexual violence against civilians), however, not only impacts on individuals, but also affects and even destroys social and communal ties (Derluyn, Vindevogel \& De Haene, 2013).

In the post-conflict phase, former child soldiers need to recover individually, given their exposure to past adverse war-related experiences and also to ongoing daily stressors (Amone-P'Olak, 2006; Baines, 2007; Betancourt, Simmons, Borisova, Brewer, Iweala, \& de la Soudière, 2008; Shanahan, 2008). In particular, once back home, youths who had at some point suffered abduction, continue to face various challenges (e.g. Amone-P'Olak 2005; Vindevogel et al., 2013), particularly stigmatization and discrimination within the communities and networks they are returning to (Baines, 2007; Betancourt, AgnewBlais, Gilmanc, Williamsd, \& Ellise, 20I0; Kligerman, 2009; Vindevogel et al., 2013). This is obviously related to the disruption of the social tissue due to the long-lasting and specific nature of the armed conflict.

Consequently, both state and non-state actors supporting recovery processes of former child soldiers recognize the need to implement interventions to support communities to welcome and reaccept their children and youth when coming back from the armed faction. Further, these interventions may also contribute to broader peace-building and reconciliation processes (Annan, Brier \& Aryemo, 2009; Baines, 2007), which are also increasingly considered as prerequisites for conflict resolution and for the prevention of a re-escalation of conflicts in the future (Bar-Tal, 2000; Bercovitch \& Kadayifci-Orellana, 2002; Nannyonjo, 2005). Reconciliation here refers to restoration of relationships, broken as a result of conflicts (e.g., Bloomfield, 2006). Most programmes and interventions set up in this framework target the individual behaviour of community members towards, for example, former child soldiers or victims of war-related violence. In this respect, government and non-government actors have implemented various programmes (e.g. Mercy Corps-Uganda, 2009; USAID, 20I0; United Religions Initiative \& ARLPI, 20I2). Local traditional reconciliation programmes such as "Nyono tong gweno" (stepping on the egg), "kayo cuk" ("biting of hot charcoal")'and "moyo kum" (a cleansing ceremony) (see Amone-P’Olak, 2006; Baines, 2007; Huyse, \& Salter, 2008; Nakayi, 2008; Shanahan, 2008) were also used to promote reacceptance of former child soldiers. Local and international psychosocial programmes (e.g. reception centres) provided psychological and social support to individuals (Idraku, 20II; McKay \& Mazurana, 2004). However, little attention has been given to reconciliation as a means of achieving post-conflict recovery (Bar-Tal, 2000) and it is not known whether reconciliation programmes are indeed able to change hostile behaviours of community members (see e.g. Baines, 2007; Boothby, Crawford, \& Halperin, 2006) and promote positive reconciliation attitudes. Reconciliation attitudes in this study are viewed as attitudes towards a person or group of persons 
perceived as having hurt the agent (of the attitudes), and as comprising four dimensions of goodwill, future orientation, avoidance and revenge attitudes. These attitudes predict whether an individual will or will not reconcile. Therefore, this study sought to examine the association between reconciliation programmes and the reconciliation attitudes of war-affected adolescents living in two post-conflict communities in Northern Uganda, comparing reconciliation attitudes of young people living in one of the communities that benefited from a peace and reconciliation intervention programme to another group of youths living in a community that did not receive any such intervention.

\section{Methods}

Study setting

This study was carried out in 20ro, four years after the cessation of active combat between the LRA and Uganda government in Northern Uganda. The LRA rebellion began in I986 following a military coup, and the deposed national army, known then as Ugandan National Liberation Army (UNLA) largely composed of people from Northern Uganda (and predominantly of the Acholi ethnic group), fled and regrouped in Sudan (Carlson \& Mazurana, 2008). During the insurgency, the LRA committed atrocities including rape, the killing of unarmed people, mutilation, sexual enslavement, and abduction of in particular young boys and girls alongside adults (World Vision, 2004; Human Rights Watch, 2005). Further, the rebels looted and burned houses, food granaries, shops, and villages in Northern Uganda (Amone-P'Olak, 2007). The abducted children were conscripted into the LRA, and overall, it was estimated that the LRA abducted between 20,000 and 60,000 children during the war (Pham, Vinck \& Stover, 2007). In captivity the children lived in constant fear of being attacked by government soldiers, sexually abused by rebel commanders, killed, catching diseases, and of being exposed to extreme deprivations and hardships such as lack of water, food, and clothing. They were also forced to commit atrocities against each other and against their own people by raiding, burning villages, looting and killing (Pham, Vinck \& Stover, 2007) as deterrent measures against escape from captivity since such acts helped to sever bonds between them and their own people (Amone-P'Olak 2004).

As a result of the activities of the LRA, more than 90 percent of the population was forced into internally displaced person's (IDP) camps (Pham, Vinck \& Stover, 2007; Human Rights Watch, 2005). However, these camps never guaranteed security, as also here people were continuously attacked by the rebels (Pham, Vinck \& Stover, 2007). Sometime between 2005 and 2006, the war became international, particularly with the relocation of the rebel activities to the Republic of South Sudan, the Democratic Republic of Congo (DRC) and Central African Republic (CAR) (Carlson \& Mazurana, 2008) ushering relative peace in Uganda. Many of the abducted children managed to escape, were rescued or released during or after the war, and have since returned home. They nevertheless continue to face many challenges related to reintegration within their communities (AmoneP'Olak 2005, 2007). 


\section{Pre-study}

As a first step, a pre-study survey was carried out to select communities to participate in the study. Interviews were conducted with organizations targeting peace-building and reconciliation in Northern Uganda. Information about the activities they were engaged in and where they were operating was obtained. Moreover, in order to select communities that were exposed to a rather similar level of war-related violence, government and local community leaders were interviewed. The results of this survey indicated that in Otuke district, a couple of communities benefited from peace and reconciliation interventions implemented by a local non-governmental organization (NGO), Concerned Parents Association-Uganda (CPA-U), a child-focused organization spontaneously formed in 1996 by a group of parents affected by the abduction of their children by the LRA in Northern Uganda (Idraku, 20II). CPA-U's program in Otuke district aimed, among other things, to support the reintegration processes of former abductees, by enhancing their psychosocial wellbeing, education and health, and also supporting sustainable long-term peace-building processes through reconciliation initiatives (Idraku, 20II). In line with calls that humanitarian services at all levels strengthen the capacity of families to care for the material and psychological needs of former child soldiers within their communities (Corbin, 2008), CPA-U sought to achieve their objectives by training community mediators (mostly members of parents support group - PSG). Mediators had to execute all phases of traditional cleansing ceremonies, including the identification of possible former child soldiers and relevant context figures, and the execution of the traditional cleansing ceremonies such as "nyono tongweno" (stepping on fowl eggs) (see AmoneP’Olak, 2006; Baines, 2007; Huyse, \& Salter, 2008; Nakayi, 2008; Shanahan, 2008) in order to promote reconciliation and forgiveness. These traditional ceremonies use extant cultural beliefs and community processes that traditionally protected and supported children (Betancourt \& Khan, 2008), and were familiar and known to the child, family and community, and were thus more culturally-sensitive and engaging than other treatment models (IASC, 2007). Further, the community mediators employed dialogue meetings and community monitoring to identify community members in need of reconciliation, and with the help of government, traditional and local leaders mediated and resolved conflicts on personal, community and societal levels. Radio talk shows, music, dance and drama were used in combination with these methods to sensitize the population to the need for conflict resolution and reconciliation. Issues addressed included, amongst other themes, conflicts arising from gender-based and domestic violence, early marriages and land ownership (Idraku, 20II).

However, this program was only implemented in some sub-counties of the district. At the time of the survey (2010), some sub-counties within the district, including Adwari sub-county, were covered by this programme, while one community, Olilim sub-county (being rather geographically remote), was not. Consequently, for comparison purposes, and because of similar levels of rebel activities and exposure to war-related stressors in both areas, the communities of Adwari and Olilim were purposively selected to form the study contexts of this research. 


\section{Study sample and procedure}

Overall, four hundred and forty five adolescents, both in- and out-of-school, living in the two communities of Adwari and Olilim sub-counties (Otuke district, Northern Uganda) were included in the study. The school-going children were met in the secondary schools in each community $(n=2)$. All pupils aged between $\mathrm{I}_{3}$ and $2 \mathrm{I}$ years old (inclusive) and who were present at the time of the study $(n=286$, out of a total of about 560 students: I87 out of 400 from Adwari Secondary School, and 99 out I6o from Otuke Secondary School (in Olilim)) were involved. Out-of-school adolescents ( $\mathrm{n}=\mathrm{I} 5 \mathrm{I}$ ) who met the inclusion criteria (having attained the age of $\mathrm{I}_{3}$ and not being older than $2 \mathrm{I}$ years, and living in one of the two targeted communities) were reached and recruited into the study with the help of local leaders. Some socio-demographic characteristics from both groups are depicted in table $\mathrm{I}$.

\begin{tabular}{|c|c|c|c|c|c|}
\hline & & Total group & Olilim & Adwari & \\
\hline & & & & & $\mathrm{X}^{2} / \mathrm{t}$ \\
\hline & & $(n=445)$ & $(\mathrm{n}=\mathrm{I} 99)$ & $(n=246)$ & \\
\hline \multirow[t]{3}{*}{ Gender } & Male & $277(62.2)$ & $\mathrm{I} 24(62.3)$ & I53 (62.2) & \\
\hline & & & & & 0.005 \\
\hline & Female & I68 (37.8) & $75(37.7)$ & $93(37.8)$ & \\
\hline \multirow[t]{3}{*}{ Residential Status } & Both Parents & $213(50.1)$ & $92(2 \mathrm{I} .6)$ & I2I (28.5) & \\
\hline & One parent & 94 (22.I) & $54(\mathrm{I} 2.7)$ & $40(9.4)$ & $8.4 \mathrm{I}^{\star \star}$ \\
\hline & Other & II $8(27.8$ & 45 (го.6) & $73(\mathrm{I} 7.2)$ & \\
\hline Age (years) & Mean (SD) & $\mathrm{I} 7.04(\mathrm{I} .88)$ & $17.24(\mathrm{I} .96)$ & I6.89 (I.8I) & $\mathrm{I} 7 \cdot 48^{\star}$ \\
\hline
\end{tabular}

$\mathrm{N}(\%) ;{ }^{*} \mathrm{p}<.05,{ }^{* *} \mathrm{p}<.01,{ }^{* * *} \mathrm{p}<.001$

Table 1: Socio-demographic characteristics of adolescents.

Local research assistants were trained for three days in questionnaire administration techniques and helped with the administration of the questionnaires. As a first step, the objectives of the study were explained to the participants, and they were assured that they were free to withdraw from the study at any time. The participants were also informed that should the need arise for psychological and/or medial services, clinical psychiatric officers and medical doctors were present at Lira Regional Referral Hospital and would provide help. A written informed consent was obtained from each of them, and thereafter, all the participants completed, in small groups and under the supervision of research assistants, self-report questionnaires. In case participants could not read or write, questionnaires were read aloud and responses recorded.

Approval for the study was obtained from the Ugandan National Council for Science and Technology (UNCST), the Ethical Committee of Ghent University, and local leaders (Resident District Commissioner, sub-county chiefs, Local Council chairpersons and the head teachers of the schools involved in the study). 


\section{Measures}

A self-report instrument assessed socio-demographic characteristics (i.e. age, gender and place of residence either in Olilim or Adwari community) of the participants. Exposure to war-related stressors were assessed using the Stressful War Events (SWE) questionnaire (Mels, Derluyn, Broekaert \& Rosseel, 20I0), questioning I6 war-related events on a yes/no scale. The questionnaire was designed to collect war-related experiences of war-affected adolescents in the eastern part of Africa. Daily stressors experienced were measured by the Adolescent Complex Emergency Daily Stressors Scale (ACEDSS) (Mels, Derluyn, Broekaert \& Rosseel, 20I0). The scale was designed for and used with war affected adolescents and asks participants to indicate whether or not (yes/no) they experienced 17 different daily and stigmatization-related stressors (e.g., lack of food and medical care, forced marriage, rejection by family).

The Openness to Reconciliation Questionnaire (Adam, 2006) assessed the reconciliation attitudes of participants. Participants were asked to keep in mind the person or group that caused them or their family harm during and/or after the war as they filled in the questionnaire. The instrument provided a list of statements presented on a Likert-scale, from I (totally incorrect) to 5 (entirely correct), and participants are asked to show their level of agreement with each item. The total score includes 33 items with four subscales: goodwill ( 8 items, e.g., 'I can sympathize with the enemy'); avoidance ( 8 items, e.g., 'I would never talk with the adversary'); revenge ( 8 items, e.g., 'I'll pay the opponents one day'); and, future orientation ( 9 items, e.g., 'I try to focus on the future'). For the subscales 'goodwill' and 'future orientation', higher scores indicate more positive attitudes, while for the subscales 'revenge' and 'avoidance', higher scores indicate more negative attitudes. The sub-scales have good internal consistency (Cronbach's alpha): goodwill, 0.79; future orientation, 0.73 ; avoidance, 0.70 ; and revenge, 0.77 .

\section{Analyses}

Differences between both groups (adolescents living in Olilim and those living in Adwari communities) were analyzed with $\chi^{2}$ - and independent samples t-tests. Four hierarchical linear regression models (method: enter) were carried out to analyze possible associations between a series of independent variables including socio-demographics variables (age and gender), total number of daily stressors, total number of war-related stressors with the reconciliation attitudes (goodwill, future orientation, avoidance and revenge attitudes) as the dependent variables. A model with the demographic variables (age and gender) and total scores for daily and war-related stressors were defined for each of the four reconciliation attitudes as a first step; and secondly, the main term of place of residence and the interactions between place of residence and age, place of residence and gender, place of residence and daily stressors total score, and place of residence and warrelated total score was added. The bootstrap-procedure was used to estimate standard errors as implemented in the Lavaan-package (Rosseel, 2012) to estimate the indirect and total effects when the conditions for mediation were fulfilled. R 2.I4.I software was used to conduct all analyses (R Core Team, 2012), and alpha was set at .05. 


\section{Results}

Exposure to war-related and daily stressors

\begin{tabular}{|c|c|c|c|c|}
\hline & Total group & Olilim & Adwari & \\
\hline & & & & $\mathrm{X}^{2} / \mathrm{t}$ \\
\hline & $(\mathrm{n}=445)$ & $(n=199$ & $(n=246)$ & \\
\hline Feeling of insecurity & $382(85.8)$ & I80 (90.5) & $202(82 . \mathrm{I}$ & $5.63^{\star \star}$ \\
\hline Problems with school fees & $382(85.8)$ & I78 (89.4) & $204(82.9)$ & $3 \cdot 33$ \\
\hline Inadequate food & $357(80.2)$ & $178(89.4)$ & $179(72.8)$ & $18.26^{\star \star \star}$ \\
\hline Inadequate clothing & $38 \mathrm{I}(85.6)$ & I8I (9I.0) & $200(8 \mathrm{I} \cdot 3)$ & $7 \cdot 56^{\star \star}$ \\
\hline Illness in family & 39I (88.I) & I84 (92.5) & 207 (84.I) & $7.24^{\star \star}$ \\
\hline Lack of care & $360(80.9)$ & $184(92.5)$ & $176(71.5)$ & $29.8 \mathrm{I}^{\star \star \star}$ \\
\hline Worry about family & $366(82.2)$ & I80 (90.I) & I86 (75.6) & $15.60^{\star \star \star}$ \\
\hline Too much work & $320(72.2)$ & I63 (8I.9) & $157(63.8)$ & $18.59^{\star \star \star}$ \\
\hline Punishment & $273(6 \mathrm{I} .8)$ & I28 (64.3) & I45 (58.9) & I.6I \\
\hline Others talking ill of you and family & $334(75.4$ & I54 (77.4) & $180(73.2)$ & $\mathrm{I} .22$ \\
\hline Discriminated against & $272(6 \mathrm{I} .4)$ & I29 (64.8) & I43 (58.I) & 2.19 \\
\hline Persecution by bad spirits & $195(43.8)$ & $103(5 \mathrm{I} .8)$ & $92(37 \cdot 4)$ & $8.64^{\star \star}$ \\
\hline Feeling abandoned by family & I7I (38.4) & $90(45.2)$ & 8I (32.9) & $6.52^{\star \star}$ \\
\hline Feeling abandoned by society & I55 (35.0) & $79(39.7)$ & $76(30.9)$ & $3.68^{\star}$ \\
\hline Forced into marriage & $\mathrm{I} 24(27.9)$ & $77\left(3^{8.7}\right)$ & 47 (I9.I) & $20.04^{\star \star \star}$ \\
\hline Do not know father & $\mathrm{I} 28(28.8)$ & $75(37.7)$ & $53(2 \mathrm{I} .5)$ & $13 \cdot 4^{\star \star \star \star}$ \\
\hline Disagreement with family & $\mathrm{I} 37(30.8)$ & 74 (27.I) & $63(25.6)$ & $6.39^{\star \star}$ \\
\hline Total daily stressors (Mean; SD) & Io.64 (4.I6) & II. 8 I (3.55) & $9 \cdot 72\left(4 \cdot 3^{8}\right)$ & $5 \cdot 40^{\star \star \star}$ \\
\hline
\end{tabular}

${ }^{*} p<0.05,{ }^{* *} p<.01,{ }^{* * *} p<.001$

Table 2: Exposure of adolescents to daily stressors (ACEDSS) by community. 


\begin{tabular}{|c|c|c|c|c|}
\hline & Total & & & \\
\hline & & Olilim & Adwari & $\mathrm{X}^{2} / t$ \\
\hline & Group & & & \\
\hline & $(n=445$ & $(\mathrm{n}=\mathrm{I99})$ & $(n=246)$ & \\
\hline Death of a loved one & 404 (9I.2) & $\mathrm{I} 84(92.5)$ & $220(89.4)$ & 0.98 \\
\hline Forceful separation from family & $282(63.8)$ & I42 (7I.4) & I40 (56.9) & $10.74^{\star \star \star}$ \\
\hline Life in IDP camp & $320(72.6)$ & I77 (88.9) & $143(58.1)$ & $56.5^{8 \star \star \star}$ \\
\hline Abduction & $189(43.2)$ & $106(53 \cdot 3)$ & $83(33.7)$ & $19 \cdot 10^{\star \star \star}$ \\
\hline Witnessing violence against others & $312(70.7)$ & I5I (75.9) & I6I $(65.4)$ & $6.99^{\star \star}$ \\
\hline Victim of violence & I9O (42.8) & 9I (45.7) & $99(40.2)$ & $\mathrm{I} .24$ \\
\hline \multirow[t]{2}{*}{ Forced to commit violence } & I66 (37.6) & $92(46.2)$ & 74 (30.I) & I2. $5 \mathrm{I}^{\star \star \star}$ \\
\hline & & & & 25. \\
\hline \multirow[t]{3}{*}{ Lack of food and water } & $359(80.7)$ & I82 (9I.5) & $\mathrm{I} 77(72.0)$ & \\
\hline & & & & $6 I^{\star \star \star}$ \\
\hline & & & & 23. \\
\hline \multirow[t]{2}{*}{ Lack of education } & $343(77,4)$ & I74 (87.4) & I69 (68.7) & \\
\hline & & & & $00^{\star \star \star}$ \\
\hline Lack of medical care & $379(85.6)$ & $175(87.9)$ & $204(82.9)$ & 2.63 \\
\hline Lack of jobs and income & $358(80.8)$ & $170(85.4)$ & I88 (76.4) & $6.25^{\star \star}$ \\
\hline Wounded or disabled & 24I (54.4) & IIg (59.8) & I22 (49.6) & $4 \cdot 73^{\star}$ \\
\hline Life on streets & I86 (42.2) & $99(49.7)$ & $87(35.4)$ & $9.96^{\star \star \star}$ \\
\hline Fear of LRA rebels & $380(85.6)$ & I8I (9I.o) & I99 (80.9) & $9.01^{\star \star \star}$ \\
\hline Feeling of not being accepted & $259(58.3)$ & I34 $(65.8)$ & $\mathrm{I} 25(50.8)$ & II. $68^{\star \star \star \star}$ \\
\hline \multirow[t]{2}{*}{ Responsibility for other children } & $225(50.8)$ & II6 (58.3) & $\log (44 \cdot 3)$ & $8.72^{\star \star \star}$ \\
\hline & & I2.II & $9 \cdot 53$ & \\
\hline \multirow[t]{2}{*}{ Total war-related stressors (Mean; SD) } & & & & $7 \cdot 33^{\star \star \star}$ \\
\hline & Io.66 (3.87) & $(3.14)$ & (I.OI) & \\
\hline
\end{tabular}

${ }^{*} p<0.05,{ }^{* *} p<.01,{ }^{* * *} p<.001$

Table 3: Exposure to war-related stressor (SWE) of adolescents by community.

Although participants from both communities experienced various daily and warrelated stressors, generally, adolescents in the Olilim community experienced more daily and more war-related stressors than those in the Adwari community (tables 2,3). 
Factors impacting reconciliation attitudes

\begin{tabular}{l|l|l|l|l} 
& Total group & Olilim & Adwari & $\boldsymbol{t}$ \\
\hline & $(\mathrm{n}=445)$ & $(\mathrm{n}=199)$ & $(\mathrm{n}=246)$ & \\
\hline Goodwill & 2I.55(7.22) & 2I.30(8.03) & 2I.74 (6.53) & 358.88 \\
\hline Future & $20.04(6.82)$ & I9.29 (7.63) & 20.6I (6.08) & $397.32^{\star}$ \\
\hline Avoidant & I3.75 (7.13) & I5.37 (7.78) & I2.50 (6.3I) & $35^{8.50^{\star \star \star}}$ \\
\hline Revenge & II.I7 (8.20) & I2.86(8.99) & $9.84(7.27)$ & $366.47^{\star \star ~}$
\end{tabular}

Mean (SD); ${ }^{*} p<.05,{ }^{* *} p<.01,{ }^{* * *} p<.001$.

Table 4: Reconciliation attitudes of adolescents in the two communities.

Overall, adolescents from Olilim (non-intervention group) showed more negative reconciliation (avoidant and revenge) attitudes than the intervention group in Adwari (table 4). Further, greater standard deviations were recorded for the Olilim than for the Adwari group.

\begin{tabular}{|c|c|c|c|c|c|c|}
\hline \multicolumn{4}{|c|}{ Goodwill attitudes } & \multicolumn{3}{|c|}{ Future attitudes } \\
\hline & B & SE & $\mathrm{t}$ & B & SE & $\mathrm{t}$ \\
\hline Intercept & $18.92^{\star \star \star}$ & 4.17 & $4 \cdot 54$ & $\mathrm{I} 6.85^{\star \star \star}$ & 3.97 & 4.25 \\
\hline Gender (ref: male) & $-\mathrm{I} .28$ & 0.92 & $-\mathrm{I} .39$ & $-\mathrm{I} .35$ & 0.88 & $-\mathrm{I} .54$ \\
\hline Age & 0.09 & 0.25 & 0.37 & 0.14 & 0.24 & $0.6 \mathrm{I}$ \\
\hline ACEDSS & -0.12 & O.II & $-\mathrm{I} .08$ & -0.15 & O.II & $-\mathrm{I} .4 \mathrm{O}$ \\
\hline SWE & $0.35^{\star \star}$ & 0.12 & 2.92 & $0.40^{\star \star \star}$ & 0.12 & 3.43 \\
\hline Place of Residence (ref: Olilim) & $-14.55^{\star}$ & 6.24 & -2.33 & $-\mathrm{II} .97^{\star}$ & 5.95 & -2.01 \\
\hline Gender^Place of Residence & 0.08 & I.40 & 0.06 & 0.60 & I. 33 & 0.45 \\
\hline Age ${ }^{\star}$ Place of Residence & 0.24 & 0.36 & 0.67 & 0.14 & 0.34 & 0.40 \\
\hline ACEDSS ${ }^{\star}$ Place of Residence & $0.77^{\star \star \star}$ & 0.19 & 4.04 & $0.85^{\star \star \star}$ & 0.18 & 4.59 \\
\hline SWE`Place of Residence & 0.02 & 0.2104 & O.II & -0.23 & 0.20 & $-\mathrm{I} . \mathrm{I} 2$ \\
\hline$\Delta \mathbf{R}^{2}$ & $0.06^{\star \star \star}$ & & & $0.02^{\star \star \star}$ & & \\
\hline $\mathbf{R}^{2}$ & $0.12^{\star \star \star}$ & & & $0.13^{\star \star \star}$ & & \\
\hline Total $\mathbf{R}^{2}$ & 0.18 & & & 0.15 & & \\
\hline
\end{tabular}

ACEDSS: Adolescent Complex Emergency Daily Stressors Scale; SWE: Stressful War Events questionnaire.

\begin{tabular}{l|l|l|l|l|l|l}
\hline \multicolumn{4}{c|}{ Revenge attitudes } & \multicolumn{3}{c}{ Avoidant attitudes } \\
\hline & B & SE & $\boldsymbol{t}$ & B & SE & $\boldsymbol{t}$ \\
\hline Intercept & I.28 & 4.87 & 0.26 & 5.47 & 4.12 & I.33 \\
\hline Gender (ref: male) & $-\mathrm{I} .62$ & I.08 & - I.50 & -I.38 & $0.9 \mathrm{I}$ & - I. 52 \\
\hline
\end{tabular}




\begin{tabular}{|c|c|c|c|c|c|c|}
\hline Age & $0.3 \mathrm{I}$ & 0.29 & I.06 & 0.14 & 0.24 & $0.6 \mathrm{I}$ \\
\hline ACEDSS & $0.29^{\star}$ & 0.13 & 2.15 & $0.28^{\star}$ & O.II & 2.48 \\
\hline SWE & 0.16 & 0.14 & I.II & $0.30^{\star}$ & 0.12 & $2.5 \mathrm{I}$ \\
\hline Place of Residence (ref: Olilim) & 3.68 & 7.28 & $0.5 \mathrm{I}$ & -5.05 & 6.16 & -0.82 \\
\hline Gender ${ }^{\star}$ Place of Residence & 3.16 & I.95 & I.95 & 0.55 & I. 38 & 0.40 \\
\hline Age ${ }^{\star}$ Place of Residence & -0.22 & 0.42 & -0.53 & 0.30 & 0.36 & 0.85 \\
\hline ACEDSS^Place of Residence & 0.34 & 0.224 & I. 52 & 0.25 & 0.19 & I.30 \\
\hline SWE ${ }^{\star}$ Place of Residence & -0.33 & 0.25 & -I.35 & -0.15 & $0.2 \mathrm{I}$ & -0.70 \\
\hline$\Delta \mathbf{R}^{2}$ & $0.02^{\star}$ & & & 0.02 & & \\
\hline $\mathbf{R}^{2}$ & $0.10^{\star}$ & & & 0.17 & & \\
\hline Total $\mathbf{R}^{2}$ & 0.12 & & & 0.19 & & \\
\hline
\end{tabular}

${ }^{*} p<0.05,{ }^{* *} p<.01,{ }^{* * *} p<.001$.

Table 5: The impact of reconciliation programmes on reconciliation attitudes.

Linear regression analyses examining the impact of the intervention ("place of residence), socio-demographic factors (gender and age), and stressors (daily and warrelated stressors) on reconciliation attitudes (goodwill, future orientation, revenge and avoidant attitudes) revealed, firstly, that 'place of residence' had an impact on positive reconciliation attitudes, both as main effect (with participants from Olilim having higher scores than those from Adwari), and in interaction with the number of daily stressors: for participants from Olilim (non-intervention community), the impact of daily stressors onto positive reconciliation attitudes was much greater (positive relationship) than for participants from the community in which an intervention was set up. Further, more warrelated stressors led to significantly more positive reconciliation attitudes and also more attitudes of avoidance, while daily stressors impacted both negative reconciliation (avoidance and revenge) attitudes. Last, no impact was found for gender and age (see table 5).

\section{Discussion}

This study assessed the association between reconciliation programmes and the reconciliation attitudes of war-affected youth in Northern Uganda living in two communities of post-conflict Northern Uganda, whereby one community benefited from a peacebuilding and reconciliation programme, while the other community did not. Overall, the results indicate that the impact of the programmes was relatively limited, with there being, in particular, no impact on negative reconciliation (avoidant and revenge) attitudes that still persisted amongst the adolescents in the intervention community. Several possible explanations can be discussed to deepen this lack of impact: First, Pupavac (200I) suggested that psychosocial interventions tend to concentrate on people's feelings rather than rational thoughts, and in this way obscure other possible sources of conflict feelings (especially in the environment), which renders it hard for people to see beyond their own negative perspectives and overcome feelings of enmity. Further, this kind of intervention encourages dependence upon the intervening bodies (programmes), thereby corroding 
personal initiatives and reliance on local ties and institutions (Pupavac, 200I). Third, findings in post-conflict settings indicate that people affected by conflicts are often more concerned with everyday problems relating to difficult living conditions and rebuilding their lives than with past traumatic events, and this prevents their effective participation in programme activities (Fernando, Miller \& Berger, 2010; Iskandar-Dharmawan \& Arifin, 2006; Rasmussen et al., 2010). Therefore, to promote healing and hope, it seems essential to revitalize communities and to address all social-ecological factors (such as poverty, illness and lack of education) which probably affect programme effectiveness (Wessells \& Monteiro, 2007).

The study findings also show that the reconciliation programme even decreased the prevalence of positive reconciliation attitudes, and even though adolescents from both communities showed positive reconciliation attitudes, those from the non-intervention group had higher positive reconciliation attitudes. Moreover, the non-intervention group reported a stronger relationship between exposure to stressors and positive reconciliation attitudes, in contrast to what could have been expected given the absence of intervention. This might be explained by the fact that, lacking external interventions, the adolescents had to focus on mobilizing their own personal resources (Wessely, Bisson \& Rose, 2000) and on support that could be given by other people (including former foes) in order to cope with the stressful daily situation they are in. Given this, it is possible that the adolescents in the intervention community, while having a lot of trust in the reconciliation programmes, did not develop strong personal coping capacities, oriented towards their immediate living contexts, capacities that would help them to deal with their problems (Pupavac, 200I), and thus showed relatively weaker positive reconciliation attitudes compared to adolescents in the non-intervention community.

Further, exposure to more war-related stressors led to both more positive reconciliation attitudes, and also to more avoidance (negative) attitudes in both communities, echoing a persistent theme of post-traumatic growth literature that suffering may lead to positive personal growth (e.g., Linley, 2003; Tedeschi \& Calhoun, 2004). The finding that associate exposure to war-related stressors to negative reconciliation attitudes of avoidance and revenge, suggests coping efforts by severely maltreated children (e.g., Bal, Van Oost, De Bourdeaudhuij \& Crombez, 2003; Cardozo, Vergara, Agani \& Gotway, 2000; Thabet, Tischler \& Vostanis, 2004). However, though these findings were true for both communities, the non-intervention community experienced the impact of the stressors on reconciliation attitudes more than the intervention community, and this is related to the above described possible explanatory hypotheses.

\section{Implications}

This study showed that if post-conflict reconciliation programmes are to achieve their objectives, they should attend to broader community concerns, including improvement of the general socio-economic situations of the people. This implies that there is a need for a multi-pronged, collaborative approach that should involve, not only the local institutions and groups, but also the national governments in order to rejuvenate communities by addressing all factors in the social ecology (such as poverty, illness and lack 
of education) that may prevent people from benefiting from the programmes (Wessells \& Monteiro, 2007). Future reconciliation programmes need to identify and strengthen the specific factors that may promote reconciliation attitudes for particular affected communities.

\section{Limitations}

The study findings need to take into account some methodological limitations. First, we were not present during the time of the intervention, so we had to rely on programme providers for information on the specific content of the programme and the way it was implemented. Therefore, evaluating the programme needs to be done carefully (Bryant \& Njenga, 2006). Second, the study mainly focused on one programme (CPA-U), and thus the findings might be highly particular and not applicable to other reconciliation programmes in post-conflict settings. Third, the data used for the research purpose were based on self-reported information of participants, and might therefore not entirely capture the whole actual impact of the programme intervention. There is therefore a need to verify and carry out further research on the results in other ways. Fourth, the study was carried out quite some time after the war, and therefore some information, particularly the data on war-related stressors, might be vulnerable to errors arising from memory difficulties. Moreover, the participants of the study themselves might have changed considerably. Such facts could have led to the findings that the programmes had limited impact as noted in the study, since factors other than the programmes' effects might have accounted for the findings. Fifth, this study involved a case study of particular communities and was therefore highly specific to post-conflict Northern Uganda, and the findings cannot be applied to other post-conflict areas. Finally, the quantitative nature of the study could not permit in-depth exploration of the reconciliation attitudes measured, nor the variety of individual experiences during and after the war.

\section{Acknowledgements}

We want to thank all the young people who participated in this study. This study was carried out with the financial support of the Belgian Technical Cooperation and VLIRUOS via the HEFS Platform Harvest Call (ZIUS2013VOAogo2).

\section{References}

Adam, H. (2006). Mental health of refugee children. An empirical study of schools in Hamburg. Unpublished Habilitation, University Hospital Hamburg-Eppendorf, Hamburg.

Amone-P'olak, K. (2004) 'A Study of the Psychological State of Former Abducted Children at Gulu World Vision Trauma Centre', Torture I4(I), 24-34.

(2005) 'Psychological Impact of War and Sexual Abuse among Adolescent Girls in Northern Uganda', Intervention 3(I), 33-45.

(2006). Mental states of adolescents exposed to war in Uganda: finding appropriate methods of rehabilitation. Torture, I6(2).

(2007). Coping with Life in Rebel Captivity and the Challenge of Reintegrating Formerly Abducted Boys in Northern Uganda. Journal of Refugee Studies, 20(4). 
Annan, J. \& Brier, M., (2009). The risk of return: Intimate partner violence in Northern Uganda's armed conflict. Social Science \& Medicine, 70, 152-159.

Baines, E.K., (2007). The Haunting of Alice: Local Approaches to Justice and Reconciliation in Northern Uganda. The International Journal of Transitional Justice, I, 9I-II4.

Bal, S., Van Oost, P., De Bourdeaudhuij, I. \& Crombez, G. (2003). Avoidant coping as a mediator between self-reported sexual abuse and stress-related symptoms in adolescents. Child Abuse \& Neglect 27, 883-897.

Bar-Tal, D. (2000). From intractable conflict through conflict resolution to reconciliation: Psychological analysis. Political Psychology, 2I, 35I-365.

Bercovitch, J. \& Kadayifci-Orellana (2002). Exploring the Relevance and Contribution of Mediation in Peace Building. Peace and Conflict Studies 9(I), 2I-4I.

Betancourt, T.S. \& Khan, K.T. (2008). The mental health of children affected by armed conflict: Protective processes and pathways to resilience. International Review of Psychiatry, 20(3), 317-328.

Betancourt, T.S., Simmons, S., Borisova, I., Brewer, S.E., Iweala, U. \& de la Soudière, M., (2008). High Hopes, Grim Reality: Reintegration and the Education of Former Child Soldiers in Sierra Leone. Comparative Education Review, I; 52(4), 565-587.

Betancourt, T.S., Agnew-Blais, J., Gilmanc, S.E., Williamsd, D.R. \& Ellise, B.H. (2010). Past horrors, present struggles: The role of stigma in the association between war experiences and psychosocial adjustment among former child soldiers in Sierra Leone. Social Science and Medicine, 70(I), 17-26.

Betancourt, T.S., Borisova, I.I., de la Soudière, M. \& Williamson, J. (20II). Sierra Leone's Child Soldiers: War Exposures and Mental Health Problems by Gender. Journal of Adolescent Health, 49(I), 2I-28.

Bloomfield, D. (2006). On good terms: clarifying reconciliation. Berghof: Research Center for Constructive Conflict Management, Berghof Report No I4.

Boothby, N., Crawford, J. \& Halperina, J., (2006). Mozambique child soldier life outcome study: Lessons learned in rehabilitation and reintegration efforts. Global Public Health: An International Journal for Research, Policy and Practice, I(I), 87-I07.

Bryant, R.A. \& Njenga, F.G. (2006). Cultural sensitivity: making trauma assessment and treatment plans culturally relevant. Journal of Clinical Psychiatry, 67(2), 74-79.

Cardozo, B.L., Vergara, A., Agani, F. \& Gotway, C.A. (2000). Mental Health, Social Functioning, and Attitudes of Kosovar Albanians Following the War in Kosovo. JAMA. 2000; 284:569-577.

Carlson, K. \& Mazurana, D. (2008). Forced Marriage within the Lord's Resistance Army, Uganda. Feinstein International Center, Tufts University, May 2008. Accessed from: http://fic.tufts.edu/assets/Forced+ Marriage+within+the+LRA-2008.pdf

Corbin, J.N. (2008). Returning home: resettlement offormerly abducted children in Northern Uganda. Published by Blackwell Publishing, Oxford - UK: doi:I0.IIII/j.036I-3666.2008.01042.x.

Denov, M., (2010). Coping with the trauma of war: Former child soldiers in post-conflict Sierra Leone. International Social Work, 53(6), 79I-806.

Derluyn, I. (20Ir). Toward a New Agenda for Rehabilitation and Reintegration Processes for Child Soldiers. Journal of Adolescent Health, 49, 3-4.

Dickson-Gomez, J. (2002). Growing up in Guerrilla camps: The long-term impact of being a child soldier in El Salvador's civil war. Ethos, $30(4), 327$.

Fernando, G.A., Miller, K.E. \& Berger, D.E. (2010). Growing Pains: The Impact of Disaster-Related and Daily Stressors on the Psychological and Psychosocial Functioning of Youth in Sri Lanka. Child Development, 8I(4), II92-I2IO.

Francis, D.J. (2007). 'Paper protection' mechanisms: child soldiers and the international protection of children in Africa's conflict zones. The Journal of Modern African Studies, 45(2), 207-23I.

Honwana, A. (2008). Children's involvement in war: Historical and social contexts. The Journal of the History of Childhood and Youth, I(I), I39-I49

Human Rights Watch. (2005). Uprooted and Forgotten: Impunity and Human Rights Abuses in Northern Uganda. www.hrw.org. Index No. Ai7I2. 
Huyse, L. \& Salter, M. (2008). Traditional Justice and Reconciliation after Violent Conflict: Learning from African Experiences. International Institute for Democracy and Electoral Assistance (IDEA), Stockholm Sweden. ISBN: 978-9I-85724-28-4.

IASC, (2007). IASC guidelines on mental health and psychosocial support in emergency settings. Geneva: IASC; 2007.

Idraku, C. (20II). Local Peace-Building Initiatives: A Case Study Of Concerned Parents' Association In Lira Municipality. Unpublished Thesis for the Award of the Degree Of Master Of Arts in Peace and Conflict Studies, Makerere University. Downloaded from: http://docs.mak.ac.ug/sites/default/files/Idraku_ Charles.pdf.

Iskandar-Dharmawan, L. \& Arifin, K. (2006). Women's resilience in displacement settings: Lessons from Indonesia. Critical Half, 4(I), 23-26, at: http://www.popline.org/node/553969\#sthash.vcwwCCoX.dpuf.

Kligerman, N. (2009). Alienation in Acholiland: War, Privatization, and Land Displacement in Northern Uganda. Independent Study Project (ISP) Collection. Paper 675. Downloaded from: http://digitalcollections.sit.edu/isp_collection $/ 675$

Linley, P.A. (2003). Positive adaptation to trauma: Wisdom as both process and outcome. Journal of Traumatic Stress i6,: 6or-6ro.

McKay, S. \& Mazurana, D. (2004). Where are the girls? Girls Fighting Forces Northern Uganda, Sierra Leone and Mozambique, Their Lives After The War. Canada International Center for Human Rights and Democratic Development.

McKay, S. (2004). Reconstructing fragile lives: girls' social reintegration in Northern Uganda and Sierra Leone. Gender \& Development, I2(3), I9-30.

Mels, C., Derluyn, I., Broekaert, E. \& Rooseel, Y. (2010). The psychological impact of forced displacement and related risk factors on Eastern Congolese adolescents affected by war. Journal of Child Psychology and Psychiatry 5I, rog6-IIO4.

Mercy Corps-Uganda, (2009). Conflict Mitigation and Reconciliation Programmes in Northern Uganda, Pader Peace Program Final Report, 2007-2009. Submitted to USAID/Uganda, URL: http://pdf.usaid.gov/ pdf_docs/PDACN277.pdf

Nakayi, R., (2008). Reaching Out For Justice and Reconciliation in Northern Uganda: The Proposed War Crimes Court and Traditional Justice. University Of Notre Dame, Center For Civil and Human Rights, Working Paper No. 5. Downloaded from http://www3.nd.edu/ffindlaw/cchr/papers/rose_uganda.pdf

Nannyonjo, J. (2005). Conflicts, poverty and human development in Northern Uganda, Research Paper, UNUWIDER, United Nations University (UNU), No. 2005/47, ISBN 9291907308.

Pearn, J. (2003). Children and war. Journal of Pediatrics \& Child Health, 39, I66-I72.

Pham, P., Vinck, P., Stover, E., Moss, A., Wierda, M. \& Bailey, B. (2007). 'When the War Ends. A PopulationBased Survey on Attitudes about Peace, Justice and Social Reconstruction in Northern Uganda', (Berkley: Human Rights Center, University of California, (2007). From: http://www.law.berkeley.edu/HRCweb/ pdfs/When-the-War-Ends.pdf

Pham, P.N. \& Stover, E., (2009). Returning home: forced conscription, reintegration, and mental health status of former abductees of the Lord's Resistance Army in Northern Uganda. BMC Psychiatry 9, 23.

Pupavac, V. (200I). Therapeutic Governance: Psycho-Social Intervention and Trauma Risk Management. Disasters $25,358-72$

R. Core Team, (2012). R: A language and environment for statistical computing. R Foundation for Statistical Computing, Vienna, Austria. ISBN 3-90005I-07-0, URL http://www.R-project.org/.

Rasmussen, A., Nguyen, L., Wilkinson, J., Vundla, S., Raghavan, S., Miller, K.E. \& Keller, A.S. (2010). Rates and Impact of Trauma and Current Stressors Among Darfuri Refugees in Eastern Chad. American Journal of Orthopsychiatry. 8o(2), 227-236.

Rosseel, Y. (2012). Lavaan: An R Package for Structural Equation Modeling. Journal of Statistical Software, 48, I-36. URL http://www.jstatsoft.org/v48/io2/.

Shanahan, F. (2008). Cultural Responses to the Reintegration of Formerly Abducted Girl Soldiers in Northern-Uganda. Psychology \& Society, I, I-I6. 
Tedeschi, R.G. \& Calhoun, L.G. (2004). Posttraumatic Growth: Conceptual Foundations and Empirical Evidence. Psychological inquiry, I5(I), I-I8.

Thabet, A.A.M., Tischler, V. \& Vostanis, P. (2004). Maltreatment and coping strategies among male adolescents living in the Gaza Strip. Child Abuse \& Neglect, 28, 77-9I.

UN General Assembly, Impact of armed conflict on children: note / by the Secretary-General, 26 August 1996, A/5I/306, available at: http://www.refworld.org/docid/3boof2d3o.html [accessed II October 20I4].

UNICEF (2004) The State of the World's Children. Oxford: Oxford University Press, accessed from: http:// www.unicef.org/sowc98/sowc98.pdf.

United Religions Initiative (URI) \& Acholi Religious Leaders Peace Initiative [ARLPI], (2012). Mitigating Land Based Conflicts in Northern Uganda. A Publication of URI \& ARLPI, Supported by IFA/ZIVIK, 4, accessed from: http://www.uri.org/files/resource_files/Mitigating\%20Land\%20Book\%20final.pdf

Ursano, R.J. \& Shaw, J.A. (2007). Children of War and Opportunities for Peace. JAMA, 298(5), 567.

USAID. (20I0). Mid-Term Evaluation Report For Stability, Peace and Reconciliation in Northern Uganda Project (SPRING) Final. United States Agency for International Development (USAID), accessed from: http://pdf.usaid.gov/pdf_docs/PDACQ995.pdf

Vindevogel, S., Coppens, K., De Schryver, M., Loots, G., Broekaert, E. \& Derluyn, I., (2013). Beyond child soldiering: The interference of daily living conditions in former child soldiers' longer term psychosocial well-being in Northern Uganda. Global Public Health, 8, 5, 485-503.

Wessells \& Monteiro, (2007). Psychosocial Intervention and Post-War Reconstruction in Angola: Interweaving Western and Traditional Approaches in Christie, D. J., Wagner, R. V., \& Winter, D. A. (Eds.). (2007). Peace, Conflict, and Violence: Peace Psychology for the 21st Century. Englewood Cliffs, New Jersey: Prentice-Hall.

Wessely, S., Bisson, J. \& Rose, S. (2000). A systematic review of brief psychological interventions ('debriefing') for the treatment of immediate trauma related symptoms and the prevention of posttraumatic stress disorder. In Depression, Anxiety and Neurosis Module of the Cochrane Database of Systematic Reviews (eds M. OakleyBrowne, R. Churchill, D.Gill, et al.). Oxford: Update Software.

World Vision. (2004). Pawns and Politics: Children, Conflict and Peace in Northern Uganda, Kampala: World Vision Publications, accessed from: . https://www.worldvision.org/worldvision/imagelib.nsf/main/ pawns/\$file/Pawns_Of_Politics.pdf

Zack-Williams, A.B, (200I). Child Soldiers in the Civil War in Sierra Leone. Review of African Political Economy, 28(87), $73-82$. 